\title{
Tinjauan Hukum Islam terhadap Penayangan Iklan Google dalam Blog
}

\author{
Ali Musthafa*, Yayat Rahmat Hidayat \\ Prodi Akuntansi, Fakultas Ekonomi dan Bisnis, Universitas Islam Bandung, \\ Indonesia.
}

*Alimusthofa204@gmail.com, yayatrahmat92@gmail.com

\begin{abstract}
This thesis is the result of a library research entitled "Review of Islamic Law Against Displaying Google Adsense Ads in Blogs". This study aims to answer the question of how the process of cooperation agreements and mechanisms for displaying advertisements on blogs, how the implementation of cooperation agreements on displaying advertisements on blogs and how the provisions of Islamic law on cooperation agreements displaying advertisements on blogs. This study aims to determine the mechanism of Google Adsense ads on blogs, the implementation of the contract in the display of Google Adsense ads on blogs, and a review of Islamic law on the Google Adsense ad display contracts on blogs. This type of research uses data collection techniques. The data collected in this research is data that has been obtained during the study by studying books related to problems and interviews with publishers and Google Adsense. The results of the study were then examined using descriptive verification techniques with an inductive mindset, this mindset is used to analyze specific data based on the facts of the research results then general conclusions are drawn. Which reveals the reality of the results of research. The results of this study explain that the collaboration agreement between Publisher and Google Adsense for displaying advertisements on blogs is not valid according to the review of Islamic law, because it does not fulfill several conditions of the syirkah contract, which is association in terms of allowing forbidden things to be prevented, and in terms of the contract object is not it can be seen that the advertisement that will be aired will be in conflict with or not with Islamic law, and this clearly contains the element of gharar (speculative), which will lead to the injury of the principle of 'an taradhin (mutual pleasure / like-like) between the seller and the buyer.
\end{abstract}

Keywords: Advertisement, Google Adsense, Publisher, Syirkah

\begin{abstract}
Abstrak. Skripsi ini adalah hasil penelitian kepustakaan yang berjudul "Tinjuan Hukum Islam Terhadap Penayangan Iklan Google Adsense dalam Blog". Penelitian ini bertujuan menjawab pertanyaan tentang bagaimana proses akad kerjasama dan mekanisme penayangan iklan di blog, bagaimana implementasi akad kerjasama terhadap penayangan iklan di blog dan bagaimana Ketentuan hukum Islam terhadap akad kerjasama penayangan iklan di blog. Penelitian ini bertujuan untuk mengetahui mekanisme iklan Google Adsense dalam Blog, implementasi akad dalam penayangan iklan Google Adsense dalam Blog, dan tinjauan hukum Islam terhadap akad penayangan iklan Google Adsense dalam Blog. Jenis penelitian ini menggunakan teknik pengumpulan data. Data yang dikumpulkan dalam penelitian ini adalah data yang telah diperoleh selama penelitian dengan cara mempelajari buku-buku yang berkaitan dengan permasalahan dan wawancara dengan publisher dan google adsense. Hasil penelitian itu kemudian ditelaah dengan menggunakan teknik deskriptif verifikatif dengan pola pikir induktif, pola pikir ini dipakai untuk menganalisis data khusus berdasarkan kenyataan-kenyataan dari hasil riset kemudian diambil kesimpulan yang bersifat umum. Yang mengungkapkan kenyataan kenyataan dari hasil penelitian. Hasil penelitian ini menerangkan bahwa Akad kerjasama antara Publisher dan Google Adsense atas penayangan iklan dalam blog tidak sah menurut tinjuan hukum Islam, karena tidak memenuhi beberapa syarat akad syirkah yaitu berserikat dalam hal yang memungkinkan tidak terhindarnya hal yang diharamkan, dan dari sisi objek akadnya pun tidak dapat diketahui bahwa iklan yang akan ditayangkan nantinya bertentangan atau tidak dengan hukum Islam, dan hal ini jelas mengandung unsur gharar (spekulatif), yang akan mengakibatkan cederanya prinsip 'an taradhin (saling ridho/suka sama suka) antara penjual dan pembeli.
\end{abstract}

Kata Kunci: Iklan, Google Adsense, Publisher, Syirkah 


\section{A. Pendahuluan}

Google Adsense adalah layanan iklan yang dimiliki oleh Google, dimana para pemilik situs bisa memasang iklan tersebut di situs-situs mereka dan mendapatkan penghasilan tambahan. Iklan yang muncul bermacam-macam jenisnya, bisa berupa teks, gambar, bahkan video, Namun yang pasti, semuanya menggunakan sistem kontekstual (contextual), dimana iklan tersebut akan relevan atau sesuai dengan isi halaman dimana iklan tersebut dipasang. Program Pay Per Click (PPC) milik perusahaan search engine (mesin pencari), Google Inc. ini boleh dibilang telah menjadi istilah umum untuk menyebut serangkaian program bisnis online yang ada saat ini. Dalam bisnis online, rasanya belum sempurna jika belum menyinggung Google Adsense. Faktanya, hampir semua pelaku bisnis online, baik yang memanfaatkan format situs ataupun blog, mempergunakan Google Adsense sebagai salah satu pilihan tambahan bisnis online mereka (meskipun saat ini telah bermunculan banyak program PPC baru yang tidak kalah bagusnya dengan Google Adsense).

Setiap ada pengunjung yang melihat atau mengklik situs web atau blog tersebut maka secara otomatis situs yang sudah terafilisiasi oleh pihak Google Adsense akan menampilkan secara otomatis iklan random (acak) dimana terkadang iklan tersebut berupa iklan yang berkonten negatif atau yang dilarang oleh syariah, seperti pornografi, perjudian, minuman keras, atau hal haram lainnya.Sedangkan bisnis secara syariah atau secara Islami adalah segala bentuk bisnis dengan dibatasi oleh cara mendapatkan dan memperdayakan harta agar selalu halal dan menolak hal-hal yang bersifat haram. Bisnis Islami merupakan aktifitas bisnis ekonomi dengan berbagai bentuk yang tidak ada batasan dalam hal kepemilikan harta baik itu jasa maupun barang namun dibatasi dalam hal cara memperoleh dan pendayagunaan harta lantaran aturan haram dan halal menurut Islam.

Dengan demikian, banyaknya iklan yang biasanya ditampilkan pada website publisher yang bertentangan dengan hukum Islam disebabkan keharamannya misalnya iklan judi, kasino, minuman keras dan pornografi yang sangat jelas bertentangan dengan hukum Islam, maka penulis bermaksud menganalisis penayangan iklan Google Adsense dalam Blog menurut tinjauan hukum Islam untuk menentukan boleh tidaknya Blogger melakukan kerjasama bisnis dengan Adsense untuk mendapatkan penghasilan tambahan melalui iklan yang ditayangkan dalam Blognya. Tujuan dari penelitian ini adalah Untuk mengetahui Tinjuan Hukum Islam Terhadap Penayangan Iklan Google Adsense dalam Blog.

\section{B. Landasan Teori}

\section{Konsep Akad}

Menurut para ulama Fiqh, akad didefinisikan sebagai hubungan antara ijab dan kabul sesuai dengan kehendak syariat yang menetapkan adanya akibat hukum dalam objek perikatan. Ibnu al-Qayyim al-Jauziyah menyebutkan dalil-dalil yang menunjukkan keumuman wajibnya memenuhi "akad" adalah sebagai berikut :

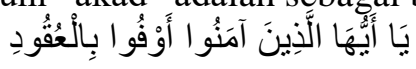

Artinya: "Hai orang-orang yang beriman, penuhilah aqad-aqad itu...”"( QS. Al-Maidah

Menurut mayoritas Ulama, rukun akad terdiri atas tiga unsur, yaitu: Shigat (ijab dan qabul), aqidan (dua pihak yang melakukan akad), dan ma"qud alaih (objek akad). Sedangkan syarat akad secara umum adalah: 1) Saling rela antara kedua belah pihak; 2) Pihak-pihak yang melakukan akad telah dipandang mampu bertindak menurut hukum (mukallaf); 3) Harta yang menjadi objek transaksi telah dimiliki sebelumnya oleh kedua pihak; 4) Objek transaksi adalah barang yang dibolehkan agama; 5) Objek akad harus dapat diserahkan secepat mungkin setelah akad berlangsung; 6) Objek akad harus jelas dan dikenali oleh pihak aqid; 7) Harga yang disepakati kedua belah pihak harus jelas jumlahnya

\section{Konsep Syirkah}

Menurut Kompilasi Hukum Ekonomi Syariah, syirkah adalah kerja sama antara dua orang atau lebih dalam hal permodalan, keterampilan, atau kepercayaan dalam usaha tertentu dengan pembagian keuntungan berdasarkan nisbah. Akad Syirkah berprinsip pada mekanisme bagi hasil, sehingga jika dalam usaha yag dilakukan mendapatkan keuntungan maupun kerugian akan 
dibagi masing-masing pihak berdasarkan besar dana yang diinvestasikan. Syirkah berdasarkan Al-Quran Surat Shad (38) ayat 24, yaitu sebagai berikut :

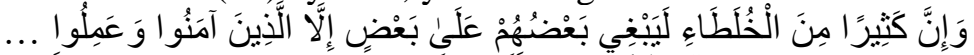

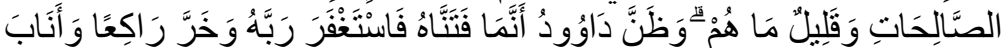

Artinya: “...Dan sesungguhnya kebanyakan dari orang-orang yang berserikat itu sebahagian dari mereka berbuat dzalim kepada sebagian yang lain, kecuali orang-orang yang beriman dan mengerjakan amal shaleh, dan amat sedikitlah mereka itu. Dan Daud mengetahui bahwa Kami mengujinya; maka ia meminta ampun kepada Tuhannya lalu menyungkur sujud dan bertaubat.

\section{Perjanjian (Kontrak) Antara Google Adsense Dan Publisher}

Kontrak yang terjadi dalam bisnis Google Adsense dilakukan secara online, dimana para pihak tidak secara langsung bertatap muka untuk melakukan kontrak kerja. Publisher disini hanya diarahkan dengan sebuah website panduan yang telah disediakan oleh Google dengan laman https://support.google.com/adsense/answer/48182?hl=id

Dari laman tersebut, publisher dapat mengikuti kebijakan-kebijakan yang harus dipatuhi sebelum menjadi mitra Google Adsense. Setelah publisher memahami dan menyetujui isi dari kebijakan-kebijakan tersebut, barulah publisher membuat akun pada Google Mail (Gmail). Pada tahap ini, publisher diperintahkan untuk mengisi identitas. Seperti nama, alamat, tempat tanggal lahir, tampat tinggal, umur dan lain-lain.

\section{Hasil Penelitian dan Pembahasan}

\section{Analisis Mekanisme Iklan Google Adsense dalam Blog}

Bisnis Google Adsense ini juga memiliki akad dan mekanisme dalam penerapannya di lapangan. Akad dan mekanisme yang dimaksud adalah bagian dari rukun syirkah yang terdapat dalam hukum Islam. Kontrak yang terjadi dalam bisnis Google Adsense ini dilakukan dalam sebuah website, di mana para pihak tidak secara langsung bertatap muka untuk melakukan kontrak kerja. Publisher di sini hanya diarahkan dengan sebuah website panduan yang telah disediakan oleh Google dengan laman https://support.google.com/adsense/answer/48182?hl=id

Google memberikan kebikajan kepada publisher bahwa, tidak boleh menempatkan kode Adsense pada halaman yang berisi konten yang melanggar pedoman kebijakan Google Adsense. seperti: 1)Konten pornografi, dewasa, atau vulgar; 2)Konten yang mengerikan; 3) Konten yang mengancam atau memprovokasi untuk menyakiti diri sendiri atau orang lain; 4) Konten yang melecehkan, mengintimidasi, atau menindas individu atau kelompok individu; 5) Konten yang menghasut kebencian, mendukung diskriminasi, meremehkan individu atau kelompok berdasarkan ras atau suku, agaman, disabilitas, usia, kebangsaan, status veteran, orientasi seksual, jenis kelamin, identitas gender, atau karateristik lain yang terkait diskriminasi atau merginalisasi sistematis; 5) Bahasa tidak sopan yang berlebihan; 6) Konten hacking, cracking; 7) Software atau konten lainnya yang melanggar kebijakan software yang tidak diinginkan; 8) Konten narkoba dan peralatan terkait; 9) Penjualan senjata atau amunisi; 10) Penjualan online minuman beralkohol.

Pada prakteknya, banyak iklan yang ditampilkan pada website publisher yang bertentangan dengan hukum Islam disebabkan keharamannya misalnya iklan judi, kasino, minuman keras dan pornografi yang sangat jelas bertentangan dengan hukum Islam, contohnya seperti iklan judi togel dalam konten/blog kesehatan dalam web Kurazone.net https://www.kurazone.net/2019/11/tips-aman-dan-cepat-hamil-yang-wajib-diketahui.html atau Iklan dengan gambar pornografi pada blog kesehatan dalam web Formispainitutorialku https://initutorialku.blogspot.com/2019/06/cara-diet-sehat-ala-artis-korea-efektif.html,

\section{Analisis Implementasi Akad dalam Penayangan Iklan Google Adsense dalam Blog}

Secara teoritis, pola syirkah yang berlaku antara Google dan publisher lebih mengarah kepada pola syirkah al-amal, karena kedua belah pihak memberikan kontribusi kerja tanpa kontribusi modal sementara keuntungan dibagi secara profesional yaitu 68\% untuk publisher dan $32 \%$ untuk Google.

Dalam melakukan kontrak, klausul-klausul yang disepakati merupakan klausul-klausul 
yang dibuat secara pihak oleh Google sehingga publisher tidak memiliki hak kebebasan berkontrak atau dengan kata lain klausul akad yang dibuat merupakan kontrak baku dari pihak Google. Hal itu dilakukan dengan pertimbangan untuk menghindari moral hazard (tindakan salah satu pihak yang dapat menyebabkan kerugian pada pihak yang lain) dari publisher, karena perjanjian dilakukan secara online dan hal itu berpotensi terjadinya penyelewengan baik sistem maupun dalam aplikasinya.

Untuk pemasarannya Google mengirim iklan- iklan ke blog para anggotanya tanpa mendapat persetujuan terlebih dahulu dari pihak anggota/publisher terkait konten iklan yang ditayangkan. Dan dalam mengirimkan iklan-iklannya, pihak Google tidak melihat apakah situs itu berbayar atau tidak, tetapi yang menjadi pertimbangan Google dalam mengirimkan iklan adalah jumlah pengunjung situs/blog dari publisher tersebut. Iklan-iklan tersebut bermacammacam, dan memungkinkan iklan tersebut ada yang bertentangan dengan hukum Islam. Iklan yang biasanya ditampilkan pada situs/blog publisher yang bertentangan dengan hukum Islam disebabkan keharamannya misalnya iklan judi, kasino, minuman keras dan pornografi yang sangat jelas bertentangan dengan hukum Islam, contohnya seperti iklan judi togel dalam konten/blog kesehatan pada situs/blog Kurazone.net https://www.kurazone.net/2019/11/tipsaman-dan-cepat-hamil-yang-wajib-diketahui.html atau Iklan dengan gambar pornografi pada situs/blog kesehatan dalam web Formispainitutorialku https://initutorialku.blogspot.com/2019/06/cara-diet-sehat-ala-artis-korea-efektif.html,

\section{Tinjauan Hukum Islam Terhadap Akad Penayangan Iklan Google Adsense dalam Blog}

Dari fakta yang ditemukan bahwa ternyata Dalam kesepakatan antara publisher dan Google Adsense, Google menerapkan format baku artinya, karena Google merupakan perusahaan yang bersifat umum sehingga tidak menutup kemungkinan ada beberapa komoditi atau iklan yang ditayangkan oleh google merupakan hal yang makruh bahkan haram dalam hukum Islam. Hal tersebut jelas dilarang dalam Islam karena adanya unsur perserikatan dalam hal yang diharamkan oleh syariat, serta membantu, mengumumkan dan menyebarkan kemungkaran terhadap iklan tersebut. Sekalipun Google Adsense memiliki banyak kemashlahatan, tetapi yang seharusnya diutamakan adalah meninggalan kemafsadatan, hal ini seseuai dengan kaidah fikih yang menyatakan:

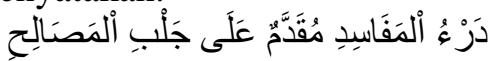

Artinya: mencegah kerusakan lebih utama dari pada menarik kemanfaatan

Kaidah ini menegaskan bahwa apabila pada waktu yang sama dihadapkan kepada pilihan menolak kemafsadatan atau meraih kemaslahatan maka yang harus didahulukan adalah menolak kemafsadatan, karena dengan menolak kemafsadatan berarti juga meraih kemaslahatan.

Hal ini pun jelas suatu perbuatan zalim yang keharamannya dipertegas oleh Allah dalam firmannya:

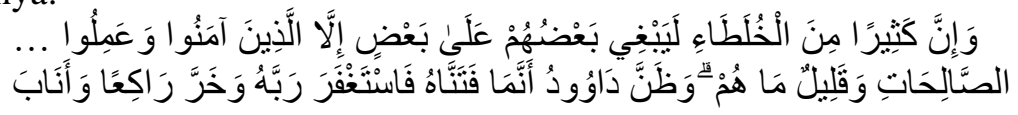

Artinya: “...Dan sesungguhnya kebanyakan dari orang-orang yang berserikat itu sebahagian dari mereka berbuat dzalim kepada sebagian yang lain, kecuali orang-orang yang beriman dan mengerjakan amal shaleh, dan amat sedikitlah mereka itu. Dan Daud mengetahui bahwa Kami mengujinya; maka ia meminta ampun kepada Tuhannya lalu menyungkur sujud dan bertaubat.

Jadi dapat disimpulkan bahwa hukum Islam tidak membolehkan bergabung dalam Google Adsense kecuali setelah memastikan bersihnya berbagai situs yang diiklankan dari halhal yang haram, karena tidaklah diperbolehkan mengumumkan, mengiklankan, dan membantu untuk menyebarkan kemungkaran. Dan akad kerjasama antara Publisher dan Google Adsense atas penayangan iklan dalam blog tidak sah menurut tinjuan hukum Islam, karena tidak memenuhi beberapa syarat akad syirkah yaitu berserikat dalam hal yang memungkinkan tidak terhindarnya hal yang diharamkan, dan dari sisi objek akadnya pun tidak dapat diketahui bahwa iklan yang akan ditayangkan nantinya bertentangan atau tidak dengan hukum Islam, dan hal ini jelas mengandung unsur gharar (spekulatif), yang akan mengakibatkan cederanya prinsip 'an taradhin (saling ridho/suka sama suka) antara penjual dan pembeli. 


\section{Kesimpulan}

Berdasarkan kajian yang telah penulis lakukan pada penelitian ini baik secara teoritis maupun analisis, akhirnya sampailah pada tahap kesimpulan. Pada bagian kesimpulan ini, ada beberapa hal yang menurut penulis anggap penting untuk dijadikan suatu konklusi dari pembahasan mengenai Tinjauan Hukum Islam terhadap Akad Kerjasama Penayangan Iklan dalam Blog:

1. Bisnis Google Adsense memiliki akad dan mekanisme dalam penerapannya di lapangan. Kontrak akad yang terjadi dalam bisnis Google Adsense ini dilakukan dalam sebuah website, di mana para pihak tidak secara langsung bertatap muka untuk melakukan kontrak kerja. Publisher di sini hanya diarahkan dengan sebuah website panduan yang telah disediakan oleh Google dengan laman https://support.google.com/adsense/answer/48182?hl=id.

2. Dalam imlpelentasi penayangan iklan dari Google Adsense memungkinkan menayangkan iklan yang bertentangan dengan hukum Islam seperti iklan judi, kasino, minuman keras dan pornografi. Karena dalam melakukan kontrak, klausul-klausul yang disepakati merupakan klausul-klausul yang dibuat secara pihak oleh Google sehingga publisher tidak memiliki hak kebebasan berkontrak atau dengan kata lain klausul akad penayangan iklan yang dibuat merupakan kontrak baku dari pihak Google.

3. Akad kerjasama antara Publisher dan Google Adsense atas penayangan iklan dalam blog tidak sah menurut tinjuan hukum Islam, karena tidak memenuhi beberapa syarat akad syirkah yaitu berserikat dalam hal yang memungkinkan tidak terhindarnya hal yang diharamkan, dan dari sisi objek akadnya pun tidak dapat diketahui bahwa iklan yang akan ditayangkan nantinya bertentangan atau tidak dengan hukum Islam, dan hal ini jelas mengandung unsur gharar (spekulatif), yang akan mengakibatkan cederanya prinsip 'an taradhin (saling ridho/suka sama suka) antara penjual dan pembeli

\section{E. Saran}

1. Bagi publisher, hendaknya mempertimbangkan aspek-aspek hukum islam dalam berbisnis dengan Google Adsense.

2. Bagi google, hendaknya bisa memfilter iklan-iklan yang bertentangan dengan hukum Islam pada situs/blog yang dimiliki oleh orang yang beragama islam, supaya umat islam tidak tergolong kepada orang yang menyebarkan kemungkaran.

\section{Daftar Pustaka}

[1]. Abdul, Ghofur, Ruslan. (2015). Konstruksi Akad dalam Pengembangan Produk Perbakan Syari'ah di Indonesi. Al-Adalah. Vol XII. No. 3. Juni.

[2]. Departemen Agama. (2015). Al-Qur"an dan Terjemahnya Bandung: Diponegoro.

[3]. Djazuli, A. (2011). Kaidah-Kaidah Fiqih: Kaidah-Kaidah Hukum Islam Dalam Menyelesaikan Masalah Masalah Yang Praktis. Jakarta: Kencana.

[4]. Hasanuddin, M, Sahroni, Oni dan. (2016). Fikih Muamalah: Dinamika Teori Akad Dan Implementasinya Dalam Ekonomi Syariah. Jakarta: Rajawali Pers.

[5]. Hasil wawancara Bagus Surochman pemilik blog dalam situs www.kurazone.net, pada tanggal 25 November, pukul 15.34

[6]. Mardani. (2015). Fiqh Ekonomi Syariah Fiqh Muamalah, Jakarta: Prenamedia Group.

[7]. Siroj, Ahmad. (2012). Tinjauan Hukum Islam Terhadap Akad Kerjasama Antara Publisher dan Google Adsense", Skripsi Fakultas Syariah Institut Agama Islam Negeri Sunan Ampel, Surabaya,

[8]. Suhendi, Hendi. Fiqh (2014). Muamalah . Jakarta: Rajagrafindo Persada.

[9]. Tim Google Adsense, kebijakan program google adsense, diakses dari https://support.google.com/adsense/answer/48182?hl=id, pada tanggal 6 Januari 2020, Pukul 01.20 WIB 